\title{
CAMILAN BAWANG KHAS PROBOLINGGO DALAM MENGHADAPI PERSAINGAN PASAR NASIONAL
}

\author{
Trismawati ${ }^{1}$, Abdul Basit ${ }^{2}$, Rofika Nuriyanti ${ }^{3}$ \\ UNIVERSITAS PANCA MARGA \\ 1trismawati@upm.ac.id, 2abdulbasit@upm.ac.id, ${ }^{3}$ rofikanuriyanti@upm.ac.id
}

\begin{abstract}
ABSTRAK
Sebagai salah satu daerah penghasil bawang di Jawa Timur, Probolinggo banyak mengembangkan UMKM yang mengolah bawang merah menjadi camilan dalam bentuk kemasan. Dalam pembuatan camilan bawang, dipilih varietas yang bagus yang memiliki bulir lebih lonjong, kadar air rendah, dan rumpun anakan umbi lebih banyak. Dalam hal ini, bawang merah dengan varietas biru lancor dipilih karena memiliki kualitas yang lebih bagus dibanding varietas lainnya. Hal tersebut akan membuat bawang merah goreng yang memiliki tekstur lebih renyah. Kegiatan ini dilaksanakan di tempat produksi CV. Dua Putri Sholehah dan UD. Terus Lancar. Target utama dalam kegiatan tahun pertama adalah menyelesaikan dan membantu kendala yang dialami oleh kedua mitra yang masih belum sesuai dengan standar nasional tempat produksi. Metode yang digunakan dalam kegatan ini adalah melakukan perbaikan tempat produksi dengan berkoordinasi dan meninjau langsung dengan pihak konsultan bangunan. Dengan tingkat keamanan dan kenyamanan tempat produksi bagi kedua mitra, pendapatan dan tingkat persaingan dengan produk lain bertambah. Peran pemerintah dibutuhkan untuk menyukseskan UMKM sehingga berdampak langsung pada omset atau pendapatan dari pemilik usaha dan lingkungan sekitar.
\end{abstract}

Kata kunci : camilan bawang, pasar nasional

\begin{abstract}
As one of the biggest production of onion in east java, Probolinggo has developed many Small and Medium Enterprises (SMEs) that process onion into a snack. In making onion snacks, a good variety is chosen which has more oval grains, and lower moisture content. In this case, the red onion with Blue Lancor varieties is chosen because it has good quality than other varieties. This will make onion snacks have a more crunchy texture. This activity is held at the production site of CV. Dua Putri Sholehah and UD. Terus Lancar. The main target in the first year's activities is to solve and assist the constraints experienced by the two partners that are still not in compliance with the national standards of production. The method used in this research is to repair the production site by coordinating and reviewing directly with the building consultant. With the level of security and convenience of production sites for both partners, income and competition levels with other products increase. Government role is also needed to succeed SMEs so that it has a direct impact on the income of business owners and the surrounding environment. Keywords : onion snack, national market
\end{abstract}

\section{A. PENDAHULUAN}

Bawang merah merupakan salah satu bumbu dapur yang sering dicampur sebagai bumbu dalam hampir setiap menu masakan. Akan tetapi, saat ini bawang 
goreng bukan hanya untuk taburan bumbu masak, tetapi menjadi salah satu primadona dalam bentuk peluang usaha bawang goreng berbentuk kemasan.Dengan perkembangan teknologi yang sudah sangat modern, bawang goreng jaman sekarang rasanya lebih enak dan bertahan lama hingga berbulan-bulan tanpa harus memakai pengawet kimia.Bahkan bawang goreng sekarang sudah bisa di makan langsung seperti camilan lainnya.

Probolinggo merupakan salah satu daerah penghasil bawang di Provinsi Jawa Timur, dan sudah banyak UKM-UKM yang mengembangkan bawang merah menjadi camilan dalam bentuk kemasan. Camilan bawang goreng merupakan makanan kesukaan banyak orang, baik anak kecil sampai yang tua, laki-laki \& perempuan, dengan barbagai varian rasa seperti rasa original, rasa keju, rasa ayam bakar, rasa sapi panggang, dan lain-lain.

Dalam pembuatan camilan bawang dipilih varietas yang bagus, yakni memiliki bulir lebih lonjong, kadar air rendah, dan rumpun anakan umbi lebih banyak, sehingga dapat menghasilkan bawang merah goreng yang jumlahnya banyak dan teksturnya renyah. Diantara UKM-UKM di Probolinggo yang mengelola bawang merah menjadi camilan bawang merah dalam bentuk kemasan adalah: CV. Dua Putri Sholehah dan UD. Terus Lancar.

\section{B. LANDASAN TEORI}

Bawang merah merupakan tumbuhan yang termaksud jenis umbi lapis (Allium cepa L. var Aggregatum) adalah sejenis tanaman yang menjadi bumbu berbagai masakan Asia Tenggara dan dunia.

(http://duniaplant.blogspot.com/2015/08/pengertian-definisi-bawang-merahjenis-umbi-lapis.html).

Bunga bawang merah merupakan bunga majemuk berbentuk tandan yang bertangkai dengan 50-200 kuntum bunga. Pada ujung dan pangkal tangkai mengecil dan dibagian tengah menggembung, bentuknya seperti pipa yang berlubang di dalamnya. Tangkai tandan bunga ini sangat panjang, lebih tinggi dari daunnya sendiri dan mencapai 30-50 cm. Bunga bawang merah termasuk bunga sempurna yang tiap bunga terdapat benang sari dan kepala putik. Bakal buah sebenarnya terbentuk dari 3 daun buah yang disebut carpel, yang membentuk tiga buah ruang dan dalam tiap ruang tersebut terdapat 2 calon biji.Buah berbentuk bulat dengan ujung tumpul. Bentuk biji 
agak pipih. Biji bawang merah dapat digunakan sebagai bahan perbanyakan tanaman secara generatif (http://duniaplant.blogspot.com/2015/08/pengertian-definisibawang-merah-jenis-umbi-lapis.html). Sebagai salah satu komoditas tertinggi di pulau Jawa, bawang merah dari Probolinggo memiliki ke khasan yang unik dan mempunyai aroma yang tahan lama dibandingkan dengan bawang merah dari daerah Brebes dan Nganjuk. Selain itu, bawang merah jenis varietas biru loncor (khas Probolinggo) memiliki keunggulan, yakni lebih mengkilap dan lebih pedas (Ashari, 2017).

Berdasarkan data yang diperoleh dari Dinas Ketahanan Pangan dan Pertanian (DKPP) Kabupaten Probolinggo, luas areal tanaman bawang merah di Kabupaten Probolinggo mencapai 6.299 hektar dengan total produksi mencapai 29.102 ton dan produktivitas 8 ton per hektar. Saat ini harga jual di pasaran mencapai antara Rp 15.000 hingga 18.000 per kg. Harga bawang merah itu fluktuatif, jika produksi melimpah maka harga turun. Kalau harga mahal maka bawang merah banyak yang rusak. Namun, bawang Probolinggo mempunyai kelebihan tersendiri. Bawang merah sudah ada sejak dahulu karena didukung oleh kencangnya angin Gending. Situasi ini mendukung hama penggerak daunnya terbawa angin dan tidak bertelur di daun. Selanjutnya, Ashari menerangkan bahwa sentra tanaman bawang merah di Kabupaten Probolinggo berada di Kecamatan Gending, Dringu, Leces, Tegalsiwalan, Banyuanyar, Maron, Krejengan, Pajarakan, Kraksaan dan Sumberasih. Sekitar 74\% masyarakat Kabupaten Probolinggo berprofesi sebagai petani, hingga saat ini pengembangan tanaman bawang merah di Kabupaten Probolinggo terus meningkat.

Banyak pengembangan tanaman bawang merah di Kabupaten Probolinggo seiring dengan semakin ketatnya persaingan pasar nasional, maka banyak diwujudkan dengan olahan bawang merah yang dilakukan oleh UKM-UKM. Dengan dukungan dari Pemerintah Kabupaten Probolinggo, UKM-UKM yang ada dibekali dengan pelatihan, informasi potensi daerah (bawang merah), menajamen, dan pemberdayaan skill oleh pemilik UKM dan pekerja.

Banyak pemilik UKM dan masyarakat Probolinggo khususnya menyadari bahwa harga jual bawang merah yang sudah diolah lebih mahal dibandingkan dengan bawang merah yang dijual di sawah ketika panen. Oleh karenanya, tim pelaksana pengabdian kepada masyarakat memiliki ide dan gagasan untuk memperkenalkan icon dari daerah Probolinggo baik di tingkat nasional maupun internasional. Diantara beberapa UKMUKM pengolahan bawang merah, tim pelaksana memilih CV. Dua Putri Sholehah dan UD. 
Terus Lancar sebagai mitra. Hal ini disebabkan karena kedua mitra tersebut memiliki potensi yang sangat besar dibandingkan UKM-UKM yang lain untuk lebih meningkat omset dan penjualan ke level ekspor dan impor.

\section{METODE PELAKSANAAN}

\section{Tempat dan waktu}

Kegiatan ini dilakukan di tempat mitra CV. Dua Putri Sholehah yang beralamat di Khotimah yang beralamat di DusunTesnan RT 02 RW03 Desa Kalirejo Kecamatan Dringu Kabupaten Probolinggo dan UD. Terus Lancar bernama Achmad Marzuqi yang beralamat di Dusun Triwung RT 10 RW 04 Desa Karanggeger Kecamatan Pajarakan Kabupaten Probolinggo Provinsi Jawa Timur. Pelaksanan kegiatan ini dimulai pada bulan Mei 2018, dengan memprioritaskan tingkat kenyamanan dan keamanan produksi dari kedua mitra tersebut. Hal ini sebagaimana masukan dari Tim Reviewer Dikti (Prof. Nyoman) saat kunjungan ke mitra CV. Dua Putri Sholehah pada bulan November 2017.

\section{Tahapan dan metode pelaksanaan kegiatan}

Kegiatan ini berasal dari dana hibah Dikti tahun anggaran 2018, yang mana kegiatan tersebut merupakan bagian dari aplikasi tahun pertama Program Pengembangan Produk Unggulan Daerah (PPPUD) camilan bawang khas Probolinggo dalam menghadapi persaingan pasar nasional. Kegiatan tahun pertama pada kegiatan ini diawali dengan berhasilnya ke tahap desk evaluasi yang dipresentasikan pada bulan Novermber 2017 di Universitas Brawijaya Malang.

Selanjutnya, tim reviewer Dikti melakukan kunjungan ke mitra, dengan maksud mengamati kondisi kedua mitra, yakni CV. Dua Putri Sholehah dan UD. Terus Lancar. Prof. Nyoman selaku tim reviewer saat berkunjung ke mitra menyarankan perbaikan fisik (tempat produksi) menjadi prioritas utama di tahun pertama. Selanjutnya, pada tahun kedua memprioritaskan alat produksi dan tahun ketiga lebih kepada strategi pemasaran yang tidak hanya tingkat nasional, tetapi juga tingkat internasional.

Pada bulan Mei 2018, perencanaan RAB dan pelaksanaan perbaikan tempat produksi dimulai pada kedua mitra, yakni CV. Dua Putri Sholehah dan UD. Terus Lancar.

Pelaksanaan kegiatan kedua mitra pada saat produksi, ada beberapa hal yaitu antara lain: 


\section{a. Bahan Baku}

Untuk mendapatkan bahan camilan dari olahan bawang merah ini biasanya dilakukan pemilihan bawang merah yang berkualitas. Khusus camilan "Bawang Merah" dari bawang merah yang jenisnya varietas biru lancor. Jenis varietas biru lancor memiliki kualitas yang bagus dibanding jenis bawang merah yang lain. Pada umumnya, yang sering dijumpai bawang asli Probolinggo memang jenis bawang tersebut.Ciri-ciri bawang merah varietas biru lancor bentuknya standar, tidak terlalu kecil, kulit luarnya tipis dan memiliki isi daging bawang yang tebal (Gambar 1.2).
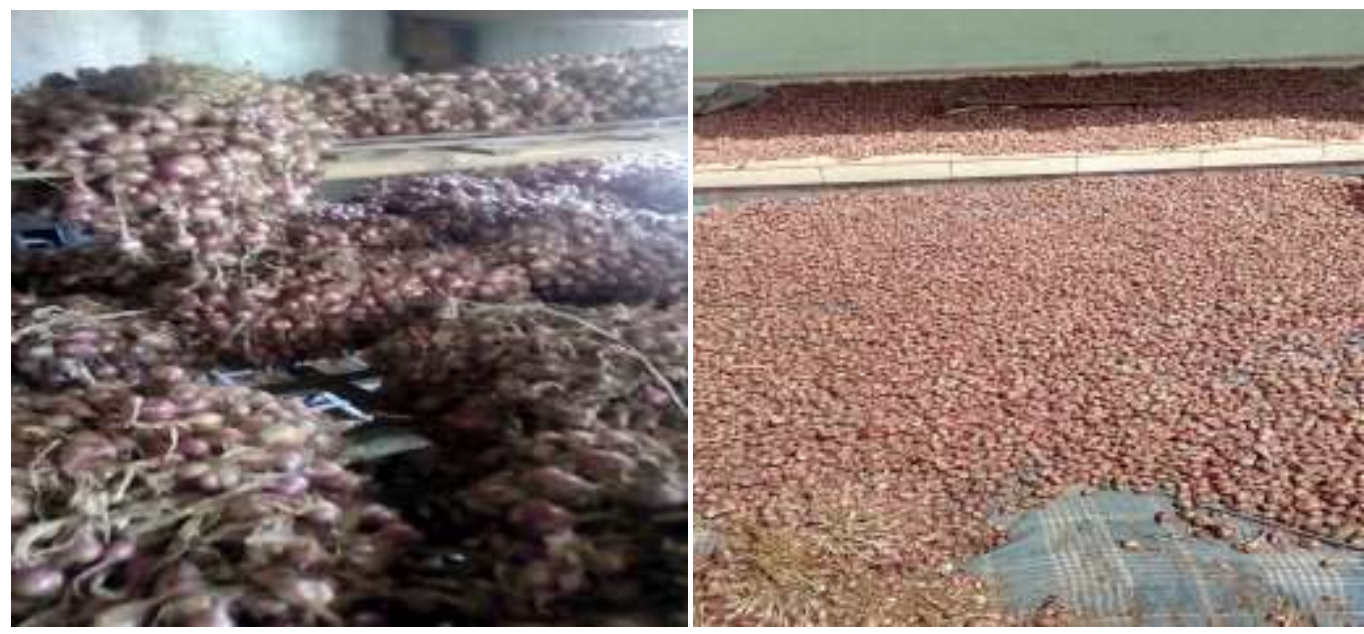

Gambar 1 Bawang Varietas Biru Lancor

Kedua mitra memperoleh bahan baku berupa bawang merah dari pedagang dan petani. Tetapi Nurul Khotimah dan Achmad Marzuqi selaku pemilik usaha biasanya mencari di pasar Sinto Dringu Probolinggo. Kapasitas kebutuhan dan stok bawang merah untuk diproduksi mencapai 1,5 kwintal/hari, sehingga jika dikalkulasikan hasil produksinya mencapai $53 \mathrm{~kg}$. Berdasarkan hasil wawancara dari mitra diketahui bahwa, ketika bawang dikemas menghasilkan 883 pcs kemasan, dengan 1 pcs seberat 60 gram, atau dalam 4 pcs terdapat 220 box.

\section{b. Produksi}

Dibandingkan hasil olahan bawang merah lainnya, jenis bawang merah varietas biru lancor lebih membutuhkan penanganan khusus dan hati-hati, terutama karena bentuk kulitnya yang sangat tipis.Oleh karena itu, diperlukan alat/mesin yang mempermudah dalam hal pengupasan bawang meras varietas biru lancor. Sementara kondisi saat ini, usaha produksi milik Nurul Khotimah (mitra 1) dan Achmad Marzuqi (mitra 2), dalam proses pengupasan bawang masih bersifat konvensional atau manual. Gambar 1.3 memperlihatkan proses pengupasan bawang yang membutuhkan banyak 
tenaga kerja, dan juga membutuhkan waktu yang lama. Hal ini selain berdampak pada peningkatan biaya produksi (gaji pekerja Rp1.500/kg/orang) juga produksi camilan bawang setiap hari masih terbatas.

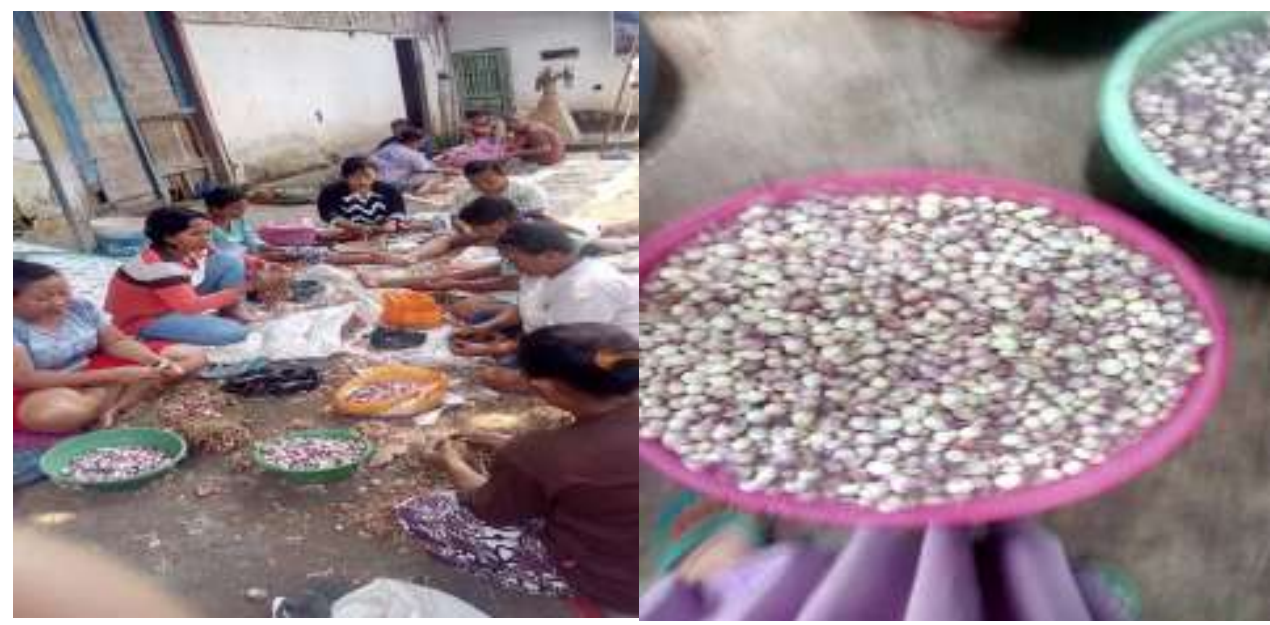

Gambar 2 Proses pengupasan bawang merah

Bawang merah yang telah dikupas nantinya akan dicuci dan dirajang serta diberi pembumbuan dengan alat yang masih konvensional dan nantinya akan digoreng dengan 200 derajat Celcius selama 30 menit.
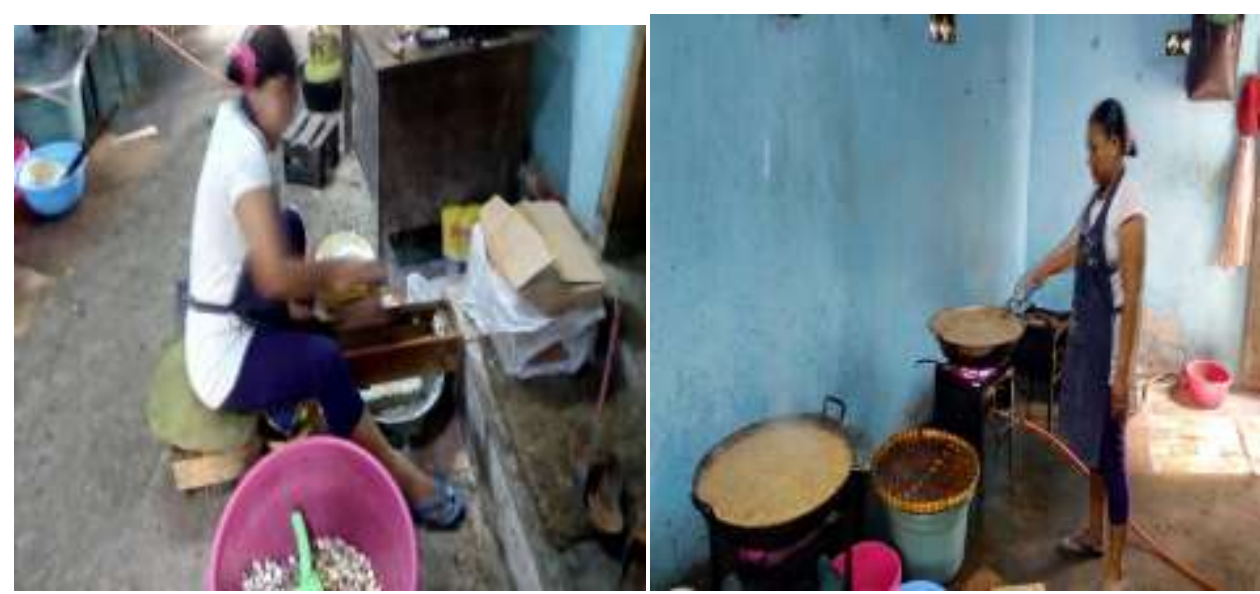

Gambar 3 Perajangan dan Penggorengan bawang merah

Selanjutnya, setelah proses penggorengan maka akan dilakukan penirisan dengan menggunakan alat spinner, seperti pada Gambar 4. 


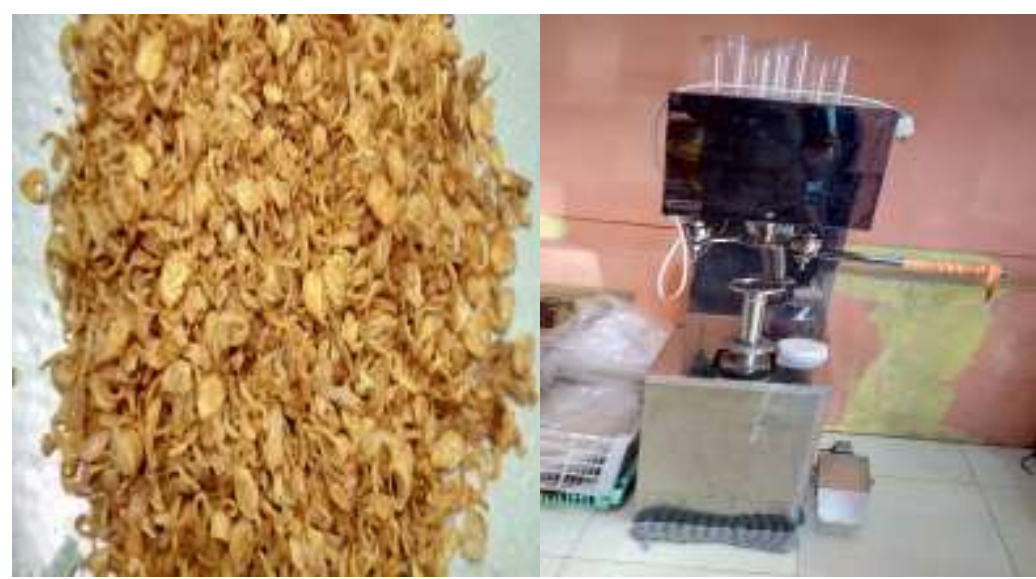

\section{Gambar 4 Penirisan dengan menggunakan spinner}

\section{c. Proses}

Dalam proses pembuatan olahan bawang merah "Camilan Bawang Goreng" terdapat alur yang ada pada kedua mitra, yakni sebagai berikut:

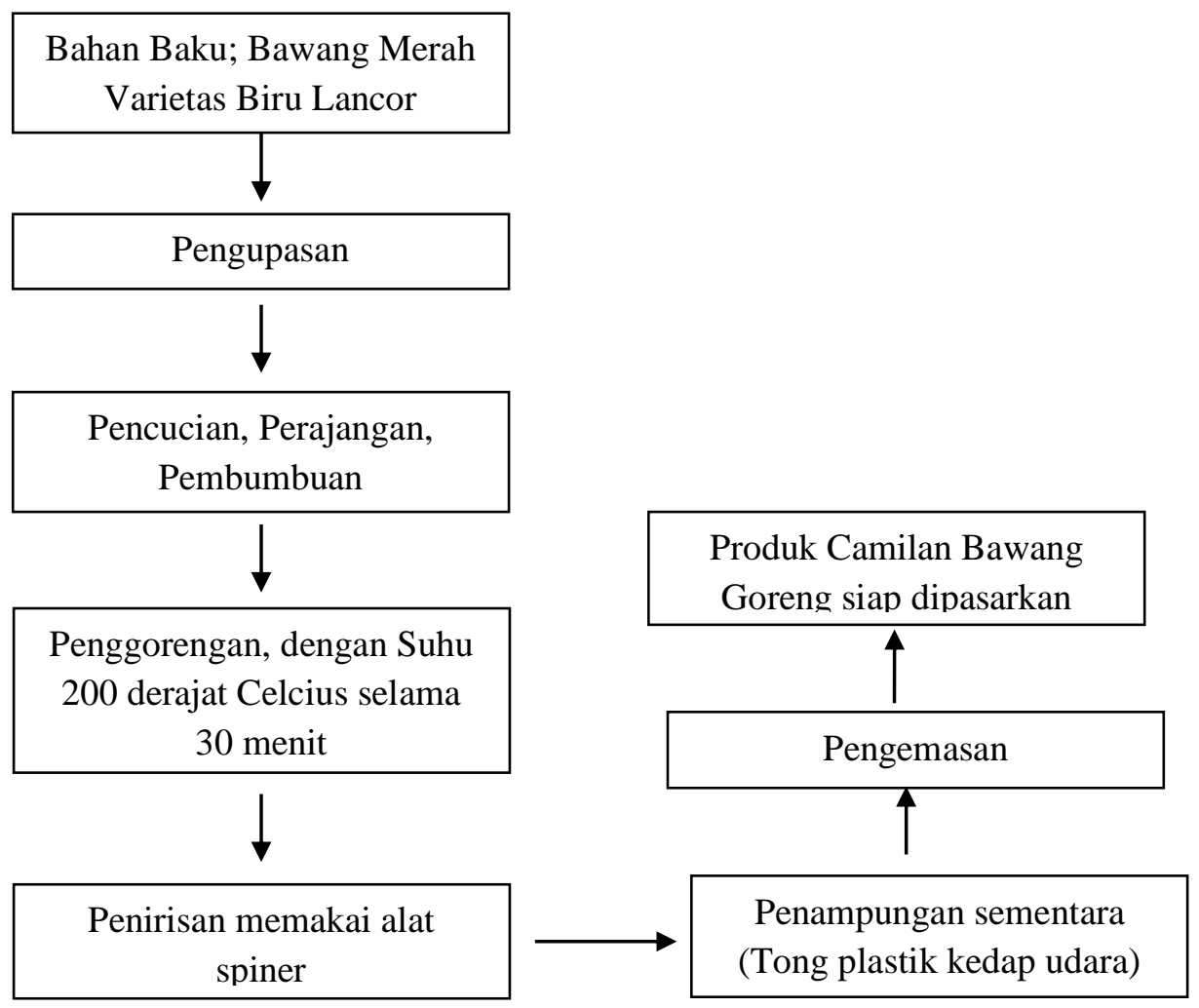

Untuk mendapatkan bawang merah yang baik dan cukup lebar, dalam proses pembuatan camilan bawang goreng mutlak dibutuhkan isi daging bawang merah jenis varietas biru lancor yang memiliki daging tebal dan kulit yang tipis. Tipis tebalnya daging (isi) bawang merah akan berpengaruh pada tingkat kapasitas produksi. Sebelum dilakukan pengupasan pada bawang merah, terlebih dahulu dilakukan 
penjemuran selama 1 hari.Penjemuran dilakukan supaya bawang merah yang diperoleh benar-benar kering dan bagus.Sebab, bawang merah yang diperoleh dari pedagang dan petani, terkadang masih dalam kondisi basah. Selain itu, dalam proses pembuatannya terutama setelah bawang merah dikupas, dirajang dan digoreng, proses selanjutnya dimasukkan ke dalam tong plastik kedap udara, sebagai tempat penampungan sementara. Pemindahan ke tong plastik guna melindungi kualitas dari hasil produksi yang sudah digoreng (Gambar 5).

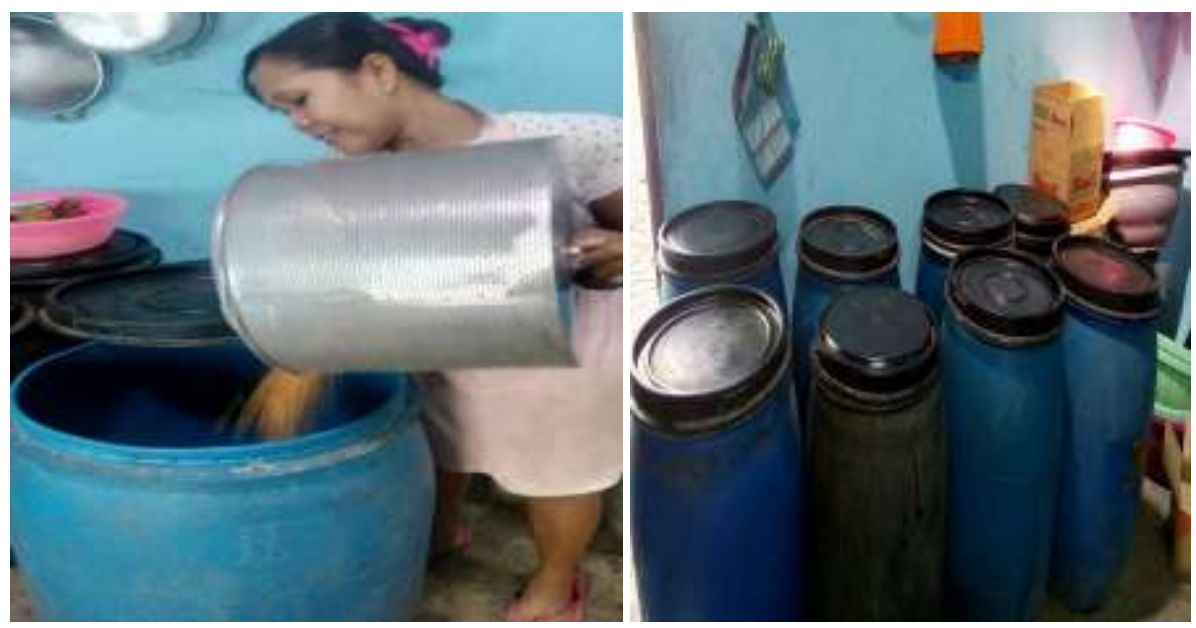

Gambar 5 Proses pemindahan camilan bawang ke tong plastik

Selanjutnya untuk menjaga mutu produk, maka dalam proses pembuatan camilan bawang goreng dari tong plastik, lalu akan dikemas dengan menggunakan alat spiner. Adapun alat packing yang dimiliki oleh mitra pertama, diantaranya handsiller dan continous bandsiller.Setelah produk dikemas dengan baik, maka camilan bawang goreng siap dipasarkan.
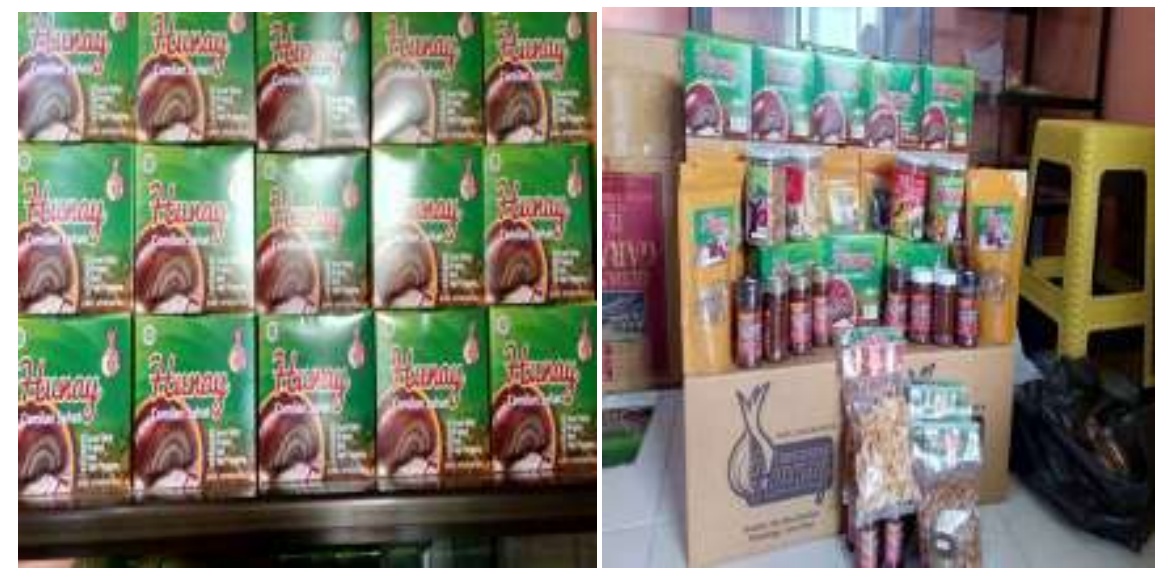

Gambar 6 Produksi camilan bawang goreng siap dipasarkan

\section{d. Produk}

Produksi "Camilan Bawang" goreng yang dihasilkan oleh CV. Dua Putri 
Sholehah (mita 1) setiap bulan dapat dilihat pada Tabel 1.

Tabel 1 Produk Bawang merah CV. Dua Putri Sholehah per Bulan

\begin{tabular}{|l|c|}
\hline Bulan & Jumlah Produksi (Kg) \\
\hline Januari & 1.550 \\
\hline Februari & 1.456 \\
\hline Maret & 1.550 \\
\hline April & 1.500 \\
\hline Mei & 1.600 \\
\hline Juni & 1.300 \\
\hline Juli & 1.400 \\
\hline Agustus & 900 \\
\hline September & 1.350 \\
\hline Oktober & 1.300 \\
\hline November & 1.450 \\
\hline Desember & 1.250 \\
\hline
\end{tabular}

\section{Sumber: Laporan pembukuan CV. “Dua Putri Sholehah pada produksi camilan bawang goreng tahun 2016}

Berdasarkan informasi yang diperoleh dari kedua mitra, UKM ini hanya mampu memproduksi 800-900 bungkus kemasan/hari, sementara permintaan pasar untuk hari-hari biasa mencapai 1000 bungkus/pelanggan. Sedangkan pada bulan-bulan tertentu, seperti hari raya Natal, Tahun Baru dan Idul Fitri bisa mencapai 2-3 kali lipat atau 2000-3000 bungkus/pelanggan toko. Sementara itu, UKM ini sudah memiliki puluhan pelanggan atau agen/distributor tetap (belum termasuk pelanggan tidak tetap) yang tersebar di Jawa Timur. Berkaitan dengan kemitraan pada perusahaan, CV. "Dua Putri Sholehah" sudah bekerja sama dengan Indomarco Prismatama Indonesia (indomart), mengisi 7 DC (Distribution Centre) untuk wilayah JABODETABEK dan Banten selama kurang lebih 2 tahun (2012-2014); Carrefour Seluruh Jawa Timur dan Bali (mulai januari 2017). Sedangkan UD. Terus Lancar pemasaran lebih banyak daerah timur, seperti Papua (Manokwari dan Irian Jaya), Bali, Sulawesi, dan lain-lain.

\section{e. Distribusi Produk hingga ke Tangan Konsumen}

Distribusi $100 \%$ dilakukan di Kota dan Kabupaten Probolinggo.Selain itu, 
distribusi dilakukan pada seluruh supermarket yang dekat dengan wilayah Probolinggo seperti daerah Malang, Pasuruan, Jember dan Surabaya.Sedangkan untuk pemasaran yang bersifat lokal, seluruh pertokoan yang ada di daerah Probolinggo.

\section{f. Manajemen}

Pola manajemen yang digunakan dalam UKM ini masih menggunakan sistem kekeluargaan dan merekrut tenaga kerja yang ada disekitar lokasi mitra.

\section{g. Pemasaran}

Untuk memenuhi permintaan konsumen saja masih kewalahan akibat keterbatasan jumlah produksi dari UKM ini, sehingga pemasaran masih bersifat lokal, yakni Kota dan Kabupaten Probolinggo dan sekitar wilayah Jawa Timur, kadangkadang melayani daerah Jawa dan Bali jika masih ada stock yang tersedia. Menurut pemilik kedua UKM, tanpa promosipun kewalahan melayani permintaan. Terkadang banyak distributor yang mengambil hasil produksi dengan kemasan yang belum diberi merk/label, sehingga para distributor menjualnya kembali.

Berdasarkan kondisi tersebut, untuk sementara dengan keterbatasan peralatan dan perlengkapan poduksi, maka hanya mampu melayani permintaan di Kabupaten Probolinggo 100-150 kg hasil olahan bawang merah per hari, Kota Probolinggo $100 \mathrm{~kg}$ per hari, dan daerah Pasuruan, Malang, Bondowoso, Blitar dan Surabaya 200 kg per hari. Pengiriman camilan bawang ke tempat-tempat yang ditujupun sesuai dengan transportasi ke daerah itu, sedangkan untuk melayani permintaan di luar pulau Jawa seperti Bali dan Papua masih melihat stock bahan baku yang tersedia.

\section{HASIL DAN PEMBAHASAN}

Berdasarkan hasil kegiatan pada Program Pengembangan Produk Unggulan Daerah (PPPUD) ini, pada tahun pertama lebih memfokuskan pada tempat industri yang sebelumnya belum aman dan nyaman, misalnya tempat penggorengan. Jarak tempat penggorengan dengan tabung gas sangat dekat (tabung gas masih ada di dalam tempat produksi), tidak rapi, dan berbahaya bagi pekerja. Hal ini menunjukkan bahwa kedua mitra masih belum menyadari pentingnya keamanan dan kenyamanan pada tempat produksinya. Sehingga tim pelaksana pengabdian pada masyarakat ini sepakat menjalankan langsung apa yang disampaikan oleh reviewer dari Dikti pada saat kunjungan langsung ke tempat mitra. Adapun proses pengerjaan tempat sedang proses 
dilakukan (diperkirakan selesai pada akhir bulan Juli 2018). Selanjutnya, tim pelaksana akan melaporkan perkembangan terkait perbaikan fisik ke Dikti pada bulan Agustus 2018.

\section{E. SIMPULAN}

Berdasarkan hasil kegiatan tersebut, dibutuhkan campur tangan pemerintah untuk lebih peduli kepada UKM khususnya UKM kecil dan menengah, sehingga hal tersebut berdampak langsung pada omset atau pendapatan dari pemilik usaha dan lingkungan sekitar, sebab pekerjanya berasal dari lingkungan sekitar dan juga berhasil meningkatkan pendapatan daerah. Tidak hanya itu, Probolinggo lebih dikenal oleh masyarakat Indonesia sebagai tempat penghasil tanaman dan produksi olahan bawang merah yang berkualitas.

\section{F. REFERENSI}

Kementerian Pertanian. 2016. Outlook Komoditas Pertanian Sub Sektor Holtikultura. Jakarta: Pusat data dan sistem informasi Pertanian.

Laporan Pembukuan CV. Dua Putri Sholehah pada tahun 2016.

http://duniaplant.blogspot.com/2015/08/pengertian-definisi-bawang-merahjenis-umbi-lapis.html

https://jatim.antaranews.com/berita/197619/dkpp-stok-bawang-merah-diprobolinggo-melimpah

https://probolinggokab.bps.go.id/Istilah/index?Istilah\%5Bberawalan\%5D=H

http://www.wartabromo.com/2017/06/07/kabupaten-muna-belajar-bawangmerah-ke-probolinggo/

https://www.google.co.id/search?q=cemilan+bawang+hunay\&tbm=isch\&tbo=u\&sourc $\mathrm{e}=$ univ\&sa=X\&ved=0ahUKEwix1 tmhyITcAhVPcCsKHYpgCUAQsAQILw\&biw=136 $6 \& b i h=662$ 